IUSLabor 3/2020

\title{
UNITED KINGDOM CRIMINAL RECORDS SCHEME: A CASE OF DISCRIMINATION WITHOUT JUSTIFICATION?
}

\author{
Iris Y. Rosario \\ Ph D student \\ Universitat Pompeu Fabra \\ "The "negative credential" associated with a \\ criminal record represents a unique mechanism of \\ stratification, in that it is the state that certifies \\ particular individuals in ways that qualify them for \\ discrimination or social exclusion. It is this official \\ status of the negative credential that differentiates \\ it from other sources of social stigma, offering \\ greater legitimacy to its use as the basis for \\ differentiation ${ }^{1}$.
}

\begin{abstract}
This paper critically examines criminal records policies in the United Kingdom and explains how they constitute an undue burden on the convicted in their path to social reintegration. It shows the limits of the European Convention of Human Rights, the European Charter of Human Rights and the International Labor Organization legal framework to accomplish the reintegration of ex-offenders into society. Finally, it proposes the reevaluation of these types of schemes, since they do not achieves their principal objective of make our societies more secure places.

Este trabajo analiza críticamente el esquema de antecedentes penales del Reino Unido y explica cómo este constituye una carga indebida en el camino hacia la reinserción de las personas condenadas. Se muestran los límites legales de los marcos jurídicos de la Convención Europea de Derechos Humanos, la Carta Europea de Derechos Humanos y la Organización Internacional del Trabajo cuando se trata de la reinserción en la sociedad de las personas condenadas. Finalmente, se propone la reevaluación de este tipo de esquemas, ya que no cumplen con su función principal de hacer nuestras sociedades lugares más seguros.

\footnotetext{
${ }^{1}$ PAGER, Debra, “The mark of a criminal record", American Journal of Sociology, Vol. 108, No. 5, 2003, p. 942.
} 
Título: Esquema de antecedentes penales en el Reino Unido: ¿un caso de discriminación sin justificación?

Key words: discrimination, criminal records and Right to work

Palabras clave: discriminación, antecedentes penales, derecho al trabajo

IUSLabor 3/2020, ISSN 1699-2938, pp. 219-238.

DOI. 10.31009/IUSLabor.2020.i03.09

Fecha envío: 22.07.2020 | Fecha aceptación: 7.10.2020

\section{Summary}

1. Introduction

2. M.M. v United Kingdom (2012)

3. The Right to Privacy or the Right to Work to Question the Criminal Records Scheme? 3.1.The Right to privacy vis a vis the "public safety"

3.2. The Right to work in the European Charter of Human Rights and in the ILO Convention

4. Are the Communities More protected by the Criminal Records Schemes or it is a case of discrimination without justification?

5. Toward a Recognition of the Ex-Offenders Right to Work without Obstacles

6. Final reflection

7. Bibliography 


\section{Introduction}

There are approximately 10 million persons imprisoned around the world ${ }^{2}$. The United States of America (USA), on the one hand, has the highest incarceration rate with nearly 2 million people behind bars. The United Kingdom (UK), on the other hand, has the first position in Western Europe with 86,000 prisoners $^{3}$. Unfortunately, punitive criminal policies in these countries do not end when people walk out from prison. On the contrary, when prisoners try to "reintegrate" into "free society" they have to carry the weight of a criminal record in their shoulders. Criminologists and lawyers have demonstrated the consequences of these policies which condemn ex-prisoners to a "hidden underworld of legalized discrimination and permanent social exclusion" . As a consequence, in some states of USA there has been recognition of the discrimination that these policies entail and legislative measures have been implemented to avoid the problem.

In the European context, the European Court of Human Rights (ECtHR) has recognized, for example, that the UK's criminal records scheme violates the right to privacy codified in the Art. 8 of the European Convention of Human Rights of 2000 (Convention). However, enacted laws don't recognize the discrimination that a person suffers when trying to access a job with a criminal record nor there is a civil remedy to ameliorate the damages.

This paper critically examines criminal records policies in the UK and explains how they constitute an undue burden on the convicted in their path to social reintegration. It proposes that - as criminology has evidenced this policies achieve precisely the opposite of the actual objective which is to prevent the convicted of committing new crimes, and should not be evaluated as a violation of the Right to privacy or the Right to work, but as an instrument of social exclusion that must be completely reevaluated.

To achieve the aforementioned objective, we will discuss in detail the ECtHR case regarding the issue of the UK's criminal records scheme: M.M. v. UK (2012) ${ }^{5}$. Consequently, Part II focuses on the implications of using the Right to privacy as a way to solve the controversy

\footnotetext{
${ }^{2} \mathrm{https} / / / \mathrm{www}$.prison-insider.com/es/ressources/analyses/rapports/tendances-mondiales-de-1-incarceration2018

${ }^{3}$ https://www.theguardian.com/society/2017/mar/14/england-and-wales-has-highest-imprisonment-rate-inwestern-europe

${ }^{4}$ AlEXANDER, Muchelle, The New Jim Crow: Mass Incarceration in the Age of Color Blindness, New York, The New Press, 2013, pp. 13.

${ }^{5}$ ECHR (2012) M.M. v. United Kingdom, (Application no. 24029/07).
} 
and tension with the so called "public safety interest". Then, a brief description of the scope of the Right to work in the European Charter of Human Rights and in the International Labor Convention will be developed. At this point, it will be important to recognize the limits to the exercise of this Right when it comes to people who have been stigmatized by the criminal machinery. Part III will examine the opinion of criminologists regarding the effects of the criminal records scheme in our societies to question the generalized idea that criminal records laws make our societies more secure places. Having transcended the above, in Part IV it will be possible to evaluate the criminal records laws as an obstacle to the ex-prisoners' freedom and as an act of coercion by the states which leads to social exclusion and delinquency.

\section{M.M. v United Kingdom (2012)}

In year 2000, a 10-month-old baby was taken in Northern Ireland by her grandma without the parents 'permission' for an entire night. Her intention was to prevent her daughter in law to return with the baby to Australia. The police were called, and the baby was returned unharmed to their parents on the morning. The grandma was arrested for child abduction and in front of her solicitor, she accepted that her conduct constituted a criminal act. The prosecutors did not initiate criminal proceedings. Instead, they offered a caution ${ }^{6}$ and she accepted. The police told her that her caution would remain on record for five years.

\footnotetext{
${ }^{6}$ According to E. Larrauri and J. Jacobs a "caution" is a warning issued by the police, without the participation of a criminal court. LARRAURI, Elena and JACOBS, James, "Disclosure of non-convictions records may violate the European Convention on Human Rights", Collateral Consequences Resource Center, January 30, 2015. Recuperado en: https://ccresourcecenter.org/2015/01/30/criminal-record-privacy-according-european-court-human-rights/
}

The ECtHR summarizes the nature of this procedure in the opinion in the next terms:

"At the relevant time the purpose of a formal caution was set out in Police Force Order no. 9/96 issued by the Royal Ulster Constabulary, namely:

“(a) to deal quickly and simply with less serious offenders;

(b) to divert offenders in the public interest from appearance in the criminal courts; and

(c) to reduce the likelihood of re-offending."

The Order further noted:

“... a formal caution is not a form of sentence ...

(a) A formal caution is nonetheless a serious matter. It is recorded by police; it may be relevant in relation to future decisions as to prosecution, and it may be cited in any subsequent criminal prosecutions. Properly used, caution is an effective form of disposal." MMv. UK, (2012), parras. 20 and 21. 
In 2006 the woman was offered an employment as "Family Support Worker", subject to a verification of her criminal record. She consented and the employer found the caution in her criminal record. The offer of employment was retired. Consequently, she wrote a letter to the Criminal Records Office questioning not only her "acceptance" of the caution, but the existence of the criminal record after 2005.

The Criminal Record Office answered the following:

"... in a case where someone agrees to be cautioned by the police for a particular offence, by doing so they are accepting that they were guilty of the offence in the first place. This information is printed on the caution form, which you signed on 17th November 2000.

Normally an adult caution will be weeded after a period of five years, provided the defendant has not been convicted of any further offences. However, following the murder of the schoolgirls in Soham England ${ }^{7}$ and the subsequent Bichard Report the weeding policy was changed in relation to all cases where the injured party is a child. The current policy is that all convictions and cautions, where the injured party is a child, are kept on the record system for life" ${ }^{\text {. }}$

In 2007, the woman applied for a job as a "Family Support Worker". The interview letter advised that the position was a regulated one under Article 31 of the Protection of Children and Vulnerable Adults (Northern Ireland) Order 2003. She was asked to complete a consent form and bring it to the interview. Eventually, the applicant was informed that her application for the position was unsuccessful. No reasons were provided.

After being rejected in two work solicitations, the woman went to ECtHR arguing that the disclosure of the caution violated the Art. 8 of the European Charter of Human Rights of 2000 (Charter):

\footnotetext{
${ }^{7}$ Two young girls were murdered in August 2002 by a caretaker employed at a local school. At the moment of the murders, he was not convicted of any crime, but he was investigated before for another crime. He did not work in the school where the girls were studying. Instead, his girlfriend was a teacher in the girls' school.

${ }^{8}$ M.M. v. United Kingdom, (2012), para. 13.
} 
"Everyone has the right to the protection of personal data concerning him or her, because it had affected her ability to secure employment in her chosen field". 9 As a consequence, she alleged, "it was necessary to examine the proportionality of the retention of the caution data on the criminal record for a prolonged period ". ${ }^{10}$

On the contrary, the position of the UK was that the retention of the data "[p]ursued the legitimate aims of public safety, the prevention of disorder or crime, the protection of health or morals or the protection of the rights and freedoms of others. Finally, retention was also necessary and proportionate" 11 .

The ECtHR initiated the analysis evaluating the UK Domestic Law, specifically, defining the nature and the aim of the caution and its recording by the Police. Then, proceeded to evaluate the complicated criminal records scheme in the UK. In that regard, the ECtHR mentions that the Police and Criminal Evidence Order 1989 authorized the recording of convictions by the police, but it did not make any references to cautions. In that sense, and as accepted by the UK Government, the recording of cautions in Northern Ireland took place under the police's common law powers to retain and use information for police purposes. Accordingly, in 2000 the Police practice was to delete a caution after five years. However, following publication of the Bichard Report, the Police changed its practice to retain information on adult cautions for the rest of a person's life.

Then, the ECtHR moved forward to consider the pertinency of the UK's Rehabilitation of Offenders Act of 1974 and the Northern Ireland Rehabilitation Act of 1978 on the matter in consideration. The Court found that, even when an ex-convict is protected by these Acts, and therefore, should be treated at the end of the incarceration as rehabilitated, the Secretary of State has the power to provide exclusions on the effect of rehabilitation. None of these Acts mention cautions, but the 1974 Act of UK contains a Schedule that authorizes the exclusion or exceptions of cautions on the effects of rehabilitation. That was not the case of the Northern Ireland Act. Regarding the Domestic Law, the ECtHR weighted the pertinency of the Data Protection Act of 1998 and the Human Right Act of 1998 on this issue. Finally, it was important to the Court that the UK Supreme Court resolved in R (L) v. Commissioner of Police of the Metropolis ${ }^{12}$ that this kind of controversy should be evaluated in terms of a proportionality test:

\footnotetext{
${ }^{9}$ M.M. v. UK, parra 181.

${ }^{10} I d$, parra 183.

${ }^{11} I d$, parra 185.

${ }^{12}$ [2009] UKSC 3.
} 
"On the one hand there is a pressing social need that children and vulnerable adults should be protected against the risk of harm. On the other there is the applicant's right to respect for her private life. It is of the greatest importance that the balance between these two considerations is struck in the right place"13.

After evaluation of the UK's Domestic Law, the ECtHR analyzed the European Law, specifically the Council and European Union Texts. Relating to this context, it took into consideration that there were principles and conventions which pretend to regulate the indiscriminate use of data when it may jeopardize the convicted person's chances of social reintegration and should therefore be restricted "to the utmost". ${ }^{14}$ In this sense, the Court highlighted the fact that any disclosure of criminal convictions based on National Law should respond to exceptional compelling grounds. At last, it mentioned the Art. 8 of the Charter and a Directive from the European Parliament regarding the use of the data by the governments.

After all, the controversy was summarized by the EChHR in these terms:

"[W]hether the data relating to the applicant's caution stored in police records constitute data relating to the applicant's "private life" and, if so, whether there has been an interference with her right to respect for private life" 15.

Then, determined that the Art. 8 of the Convention applied to this controversy because:

"[A]lthough data contained in the criminal record are, in one sense, public information, their systematic storing in central records means that they are available for disclosure long after the event when everyone other than the person concerned is likely to have forgotten about it, and all the more so where, as in the present case, the caution has occurred in private" 16 .

${ }_{13} M M_{V} U K$, parra 105 quoting the parra 42 of $R(L)_{V}$ Commissioner of Police of the Metropolis.

${ }^{14} \mathrm{Id}$, parra 142.

${ }^{15} \mathrm{Id}$, parra 187 .

${ }^{16} I d$, parra 188 . 
Taking into consideration the wide discretion that the Police had in this type of cases, the National and European Regulation of the Data Protection, and the Art. 8 of the Convention, concluded:

"The Court agrees with Lord Neuberger that it is realistic to assume that, in the majority of cases, an adverse criminal record certificate will represent something close to a "killer blow" to the hopes of a person who aspires to any post which falls within the scope of disclosure requirements (see paragraph 111 above)"17.

In addition:

"[T]he Court expresses concern about the change in policy, which occurred several years after the applicant had accepted the caution and which was to have significant effects on her employment prospects" ${ }^{\prime 18}$.

With respect to existence of a law governing these situations:

"[T]he Court highlights the absence of a clear legislative framework for the collection and storage of data, and the lack of clarity as to the scope, extent, and restrictions of the common law powers of the police to retain and disclose caution data...the Court notes the limited filtering arrangements in respect of disclosures ... no distinction is made on the basis of the nature of the offence, the disposal in the case, the time which has elapsed since the offence took place or the relevance of the data to the employment sought" ${ }^{19}$.

Finally, the ECtHR decided:

"The cumulative effect of these shortcomings is that the Court is not satisfied that there were, and are, sufficient safeguards in the system for retention and disclosure of criminal record data to ensure that data relating to the applicant's private life have not been, and will not be, disclosed in violation of her right to respect for her private life" ${ }^{\text {20. }}$

\footnotetext{
${ }^{17} I d$, parra. 200.

${ }^{18} I d$, parra. 205

${ }^{19} I d$, parra. 206.

${ }^{20} I d$, parra. 207.
} 
The resolution of this case is without doubt very important because, as E. Larrauri and J. Jacobs mentioned, it balances "the claims to public protection with the respect for the private life of its citizens and it can be seen as a contribution to the reinforcement of human rights" ${ }^{\text {. }}$. However, the opinion can be criticized for two reasons, among others: ${ }^{22}$ (1) using the Right to privacy as the foundation to resolve this controversy constitutes a trap very difficult to overcome, in view of the fact that it implicates balancing the effects of the criminal records scheme with the so called "public safety interest"; and (2) because it does not address the Right to work as the main instrument to reintegrate a person with a criminal record into "free society".

Taking into consideration these two aspects, the next section will be divided in two parts. The first will discuss the scope of the Right to privacy in the aforesaid context and, second, the Right to work and its limits in the Charter and in the International Labor Convention (ILO).

\section{The Right to Privacy or the Right to Work to Question the Criminal Records Scheme?}

\subsection{The Right to privacy vis a vis the "public safety"}

On the one hand, the European Convention of Human Rights of 1950 (Convention) recognizes the Right to privacy in its Art. 8: Everyone has the right to respect for his private and family life, his home and his correspondence.

In the same way, the European Charter of Fundamental Rights of 2000 (Charter) in Art. 8 acknowledges the existence of the Right to the protection of the personal data:

"1. Everyone has the right to the protection of personal data concerning him or her.

2. Such data must be processed fairly for specified purposes and on the basis of the consent of the person concerned or some other legitimate basis laid down by law. Everyone has the right of access to data which has been collected concerning him or her, and the right to have it rectified.

\footnotetext{
${ }^{21}$ LARRAURI Elena. and JACOBS, James, Id.

22 In this case, it could be argued that there was a violation of the ex post facto doctrine since the criminal record scheme changed after the woman accepted the caution in 2000, but I will concentrate in the issues that I already mentioned, because this paper is about Labor Law. Nonetheless, there are several issues about Criminal law and procedure that can be discussed.
} 
3. Compliance with these rules shall be subject to control by an independent authority."

On the other hand, the Convention authorizes the interference of the public authority to this Right when it is exercised

"[I]n accordance with the law and is necessary in a democratic society in the interests of national security, public safety or the economic well-being of the country, for the prevention of disorder or crime, for the protection of health or morals, or for the protection of the rights and freedoms of others".

In this sense, as the petitioner in M.M. v. UK alleged, there should be a proportionality test when the Right to privacy is at stake. The balance is between the need for the retentions and disclosure of the private data and the protections of the "public safety". Nevertheless, the concept of "public safety" is very elastic and it has been used by governments to legitimate all kind of police intervention. In that way, the states amplify its power to reduce to the minimum and to prevent crimes ${ }^{23}$. In the criminal records schemes, for instance, the idea is to alert the employers about the past criminal behavior of their potential employees. The logic (if ever) behind this idea is that, once you have been convicted, or even reached in any way by the criminal apparatus, you can be catalogued as a permanent danger to society. By doing so, the state assumes the potential of some people to re-offend and labels them as criminals forever.

In the M.M. $v . U K$ case, the UK government reacted to the Soham murders making the criminal records scheme more punitive, even when the author of the terrible crimes did not work in the same school were the victims studied. In this regard, like E. Larrauri and J. Jacobs have expressed, "[i]t is difficult to see what his CBC would have prevented" ${ }^{24}$. Unfortunately, as we've seen, the concept of "public safety" can be made wider in order to prevent crimes and to calm the so-called public opinion. That is why, although the UK was supposed to revise the criminal records scheme after the $M M$ case, the policy continues to be very punitive. As mentioned by E. Larrauri and J. Jacobs, "even with the "new filtering rules" the case of MM...would still probably be disclosed" ${ }^{25}$ because:

\footnotetext{
${ }^{23}$ See GaRLAnd, David, The culture of control", University of Chicago Press, 2001.

${ }^{24}$ LARRAURI, Elena and JACOBS, James, "Criminal record disclosure and the Right to privacy", Criminal Law Review, No. 10, 2014, pp. 739.

${ }^{25}, I d$, p. 734.
} 
"[A]ll cautions and convictions for serious violent and sexual offences and for certain other offences specified in the orders, such as those directly relevant to the safeguarding of vulnerable groups including children, will continue to be disclosed, as will all convictions resulting in a custodial sentence, 26 .

In addition, a similar case, concerning the criminal record policy, was resolved in the UK Supreme Court and the stories ${ }^{27}$ of the people involved shed light to the idea that, when it comes to "prevent crimes" and ensure the "public safety", the state is not willing to protect the Right to privacy. That is why the UK Supreme Court, ${ }^{28}$ declared in three - P's, Gallagher's and G's - of the four cases that the criminal records scheme was incompatible with Art. 8 of the Convention. But in the fourth case - W's- the majority expressed that it was proportionate to disclose a bodily harm conditional discharge since an assault is a very serious offence, even when $\mathrm{W}-47$ seven years-old- was 16 years-old at the time of the offence and the assault took place in a school fight between other boys. ${ }^{29}$

As David Garland mentioned, and Elena Larrauri reviewed, in this era of punitive populism, the governments tend to privilege the "public protections" before other Rights. The norm is to amplify the capacity of the state to "protect" the people, instead of protecting the citizenship from the government power ${ }^{30}$. Therefore, when it comes to the criminal records schemes evaluation, the emphasis should be put into the effects that these policies provoke in affected people access to work.

\subsection{The Right to work in the European Charter of Human Rights and in the ILO Convention}

In the European context, the Art. 15 of the Charter, proclaims

\footnotetext{
${ }^{26}$ In the matter of an application by Lorraine Gallagher for Judicial Review (Northern Ireland) $R$ (on the application of $P, G$ and $W$ ) (Respondents) $v$ Secretary of State for the Home Department and another (Appellants) $R$ (on the application of $P$ ) (Appellant) $v$ Secretary of State for the Home Department and others (Respondents), [2019] UKSC 3, parra. 138.

${ }^{27}$ One of the applicants, for example, had schizophrenia when she was accused in the theft of a sandwich and after the theft of a book. When filing the case before the Maximus Court she was in treatment and in good health and she was trying, unsuccessfully, to get a job as a teacher's assistant.

${ }^{28} I d$.

${ }^{29} I d$, parra 4.

${ }^{30}$ LARRAURI, Elena, "Populismo punitivo y como resistirlo", Jueces para la democracia, No. 55, Madrid, marzo de 2006, pp.15.
} 
"1. Everyone has the right to engage in work and to pursue a freely chosen or accepted occupation.

2. Every citizen of the Union has the freedom to seek employment, to work, to exercise the right of establishment and to provide services in any Member State."

In the International context, the Declaration of Philadelphia of the ILO Convention recognizes in Art. $3^{31}$ :

"[T]he solemn obligation of the International Labor Organization to further among the nations of the world programs which will achieve:

(a) full employment and the raising of standards of living;

(b) the employment of workers in the occupations in which they can have the satisfaction of giving the fullest measure of their skill and attainments and make their greatest contribution to the common wellbeing;"

In this way, there is a regional and international recognition of work as a Fundamental Right. Accordingly, and taking the Equal Protection Right as its foundation, the Charter prohibits, without specifying the context, in the Art. 21:

"Any discrimination based on any ground such as sex, race, color, ethnic or social origin, genetic features, language, religion or belief, political or any other opinion, membership of a national minority, property, birth, disability, age or sexual orientation...",

In consonance, but in this case specifying the prohibition of employment discrimination, the Art. 1 of ILO No. 111 Declaration states:

\footnotetext{
${ }^{31}$ For the purpose of this article, I am assuming Keith Ewing's theory about the binding effect of the ILO Declarations in the European context after the resolution of the ECtHR in ECHR (2008), Demir and Baycara $v$ Turkey, (Application No. 34503/97):
}

Although there may be no direct obligation under EU law to have 'legislation necessary to give effect to the provisions of the international labor conventions already ratified' by the member state in question, such an obligation arises from the EU Charter, Article 12, as informed by the jurisprudence of the ECHR (albeit through perhaps unanticipated consequence of the Charter). EwING, Keith, "The Death of Social Europe", King's Law Journal, Vol. 26, No. 1. 2015, p.85. 
"[E]mployment discrimination could be defined as any distinction, exclusion or preference made on the basis of race, color, sex, religion, political opinion, national extraction or social origin, which has the effect of nullifying or impairing equality of opportunity or treatment in employment or occupation."

There is no recognition of employment discrimination for criminal record neither in the Charter nor in the ILO No. Declaration. On the contrary, the prohibition of discrimination in the ILO No. 111 Declaration is not absolute. In that sense, the Art. 4 express states that:

"Any measures affecting an individual who is justifiably suspected of, or engaged in, activities prejudicial to the security of the State shall not be deemed to be discrimination."

As in the Right to privacy issues discussed above, an alleged violation of the Right to work through an act of discrimination, should be evaluated taking into consideration the "security of the State". That is why, for instance, the Art. 10.1 of the Directive 2011/92/EU of the European Parliament and the Council authorizes disqualifications from professional activities arising from convictions ${ }^{32}$. Therefore, in the balance between the Right to work and the "security of the state" the scales are currently tipped against the people with criminal records because "[i]n practice ... the state tends to ignore the balance". ${ }^{33}$

In light of that reality, two aspects are imperative: (1) acknowledge the employment discrimination that the UK's criminal records scheme creates; and (2) deconstruct the generalized idea that these policies are necessary in order to achieve a more secure society. In the next session, we will consider the criminology literature about this issue.

${ }^{32}$ See ECHR, Thlimmenos v. Greece, (1997) (Application no. 34369/97) where the ECtHR expressed:

"The Court considers that, as a matter of principle, States have a legitimate interest to exclude some offenders from the profession of chartered accountant. However, the Court also considers that, unlike other convictions for serious criminal offences, a conviction for refusing on religious or philosophical grounds to wear the military uniform cannot imply any dishonesty or moral turpitude likely to undermine the offender's ability to exercise this profession. Excluding the applicant on the ground that he was an unfit person was not, therefore, justified." parra. 47

${ }^{33}$ SHI HUI, "The Legislative Protection of the Equal Employment Right of Individuals with Criminal Records Based on the International Human Rights Law”, Canadian Social Science, 2017, pp. 29. 


\title{
3. Are the Communities More protected by the Criminal Records Schemes or it is a case of discrimination without justification?
}

The declared objective of criminal records legislations is to make our society more secure through the prevention of new crimes. The idea is that an ex-offender is more dangerous than others. In that sense, these policies are based on the assumption that there is a tendency to reoffend. However, it has been recognized that:

\begin{abstract}
"Employers have ... more to fear from the non-offending population than from these ex-offenders. In fact, our calculations suggest that 17 out of every thousand 30-yearolds who had a crime-free period during the previous ten years would be convicted in the next five years. Further, of those 17 persons, will have previously had no convictions at all..."34
\end{abstract}

As already seen, when it comes to recidivism and dangerousness nothing can be guaranteed: "[t]he commission of a past crime is not automatically an accurate predictor of future offending behavior. "35 But certainly, there are conditions which create the environment that push a person to re-offend or to be a law-abiding citizen. In that sense, [s]tudies have reported that employment can reduce recidivism by between a third and a half. ${ }^{36}$ In the UK context, for instance, an independent review into the treatment of, and outcomes for Black, Asian and Minority Ethnic individuals in the criminal justice system revealed that " $[p]$ risoners who find work on release are less likely to reoffend than those who do not" $"$ " Although, there is a direct relation between employment and the risk of re-offending ${ }^{38}$, the criminal records schemes are implemented widely.

\footnotetext{
${ }^{34}$ LARRAURI, Elena and JACOBS, James quoting SOOTHILL and BRIAN in "Criminal record disclosure and the Right to privacy", Vol. 2014, pp.735.

${ }^{35}$ NAYLOR, Brown; PATtERSON, Moyra and PITTARD, Marilyn, "In the shadow of a criminal record: proposing a just model of criminal record employment checks", Melbourne U. L.R. Vol. 32, No. 1, 2009, pp 189.

${ }^{36} I d$.

${ }^{37}$ LAMmy, David, "The Lammy Review of Black, Asian, and Minority Ethinc (BAME) Representationin the Criminal Justice system: call for evidence”, 2017, pp. 62.

Recuperado en: https://www.gov.uk/government/publications/lammy-review-final-report

${ }^{38}$ LARRAURI, Elena and JACOBS, James, quoting FARRAL, 2004; RICHARDS and JONES, 2004; LEVERENTZ, 2011 in "Reinserción social y antecedentes penales", Revista electrónica de ciencia penal y criminología, No. 13-09, 2011, p. 2.
} 
Regarding this aspect, and worried by the rapid expansion of the prison population in the USA and the growing population of people with criminal records, Debra Pager studied the consequences of incarceration for the employment outcomes of black and white job seekers 39. Her findings, published in 2003, demonstrated a serious problem of discrimination: in $50 \%$ of cases, employers were unwilling to consider equally qualified applicants on the basis of their criminal record.$^{40} \mathrm{But}$, the effect of a criminal record is... $40 \%$ larger for blacks than for white ${ }^{41}$. Recently, the American Civil Liberties Union announced in the web that: "[a] Los Angeles survey found that over 60\% of employers would "probably not" or "definitely not" be willing to hire an individual with a criminal record" ${ }^{2}$.

Consequently, some states and the Federal Government have enacted laws to prevent this. However, that kind of legislation is linked exclusively to the problem of racial discrimination which is caused by the overrepresentation of blacks in the criminal system. Nonetheless, it is the ACLU's opinion, that using the Civil Rights Act of 1964 to litigate ex-offender employment discrimination "have rarely been enforced in courts" 43 . More successful has resulted the "ban -the- box" movement which seeks to prohibit the question about an applicant's criminal history in job applications ${ }^{44}$. This kind of campaigns benefit all exoffenders, regardless of their race or ethnicity and it does not depend on the judiciary.

The discrimination that ex-offenders suffer in USA is repeated in other places as well. A study in the UK evidenced that employers asked for criminal records in 63 per cent of vacancies based on the "security" of their clients". Another "survey found that half of respondents would not consider employing an offender or ex-offender" 46 . This is very significant, since the UK has a "greater disproportionality in the number of Black people in prisons" than the USA; the same happens with other minorities ${ }^{47}$. As a result, some people would say that this is another case of discrimination that has a disproportionate impact on black people and other minorities. Therefore, it could be attractive, as in the USA, to construct a legal argument of indirect racial discrimination. The problem is that this kind of

\footnotetext{
${ }^{39}$ Pager, $I d$. pp. 956.

${ }^{40} I d$.

${ }^{41} I d$, pp. 959.

${ }^{42}$ Recuperado de: aclu.org/other/employment-discrimination-against-women-criminal-convictions

${ }^{43} I d$.

${ }^{44}$ https://www.nelp.org/publication/ban-the-box-fair-chance-hiring-state-and-local-guide/

${ }^{45}$ NAYlor, Brown; Patterson, Moyra and Pittard, Marilyn quoting MetCalF, ANDERSON and Rolfe, Id, pp. 188.

46 "The Lammy Review", Id. pp. 64.

47 "The Lammy Review", Id, pp. 3.
} 
legal constructions avoids to approach the real issue of discrimination: the stigmatization that an ex-offender carries in its shoulders, despite their race, gender or age. Consequently, once the problem of employment discrimination for criminal record is identified, there is a need is to prove the consequences of the criminal records schemes to the "public safety" in order to question the criminal records policy itself.

\section{Toward a Recognition of the Ex-Offenders Right to Work without Obstacles}

Once criminologists have studied and evidenced the relationship between the criminal records schemes, employment discrimination and re-offending, the declared objective of these criminal policies and its existence can be challenged. If these policies left these individuals with few viable options ${ }^{48}$, reoffending will be more likely. And then, the communities will not be adequately protected. This reality should have implications not only in the "probability test" used by courts when evaluating an interference with the Right to privacy; but in weighting the scope of the Right to work. After all, there seems to be no proper justification for this discrimination, because as the Lammy Review highlighted: "The system is there to protect the public but is having the opposite effect if it sees ex-offenders languishing without jobs and drawn back into criminality". ${ }^{49}$ It is crucial, then to look at this serious problem of social exclusion from another perspective.

Virginia Mantouvalou develops a theory about the indivisibility of Human Rights- civil and political rights, and social and economics - using a theoretical justification based on the idea of freedom. But her concept of freedom is not libertarian. On the contrary, she defends the concept of positive freedom. In her theory, liberty is not only essential to execute civil and political rights; but to accomplish social and labor rights. In this sense, people are not free if the options open to them are very limited and unappealing. ${ }^{50}$ To construct her theory, Mantouvalou is inspired in the Martha Nussbaum theory of capabilities.

"The theory of capabilities, as elaborated by Nussbaum, has as its aim 'to provide the philosophical underpinning for an account of basic constitutional principles that

\footnotetext{
${ }^{48}$ PAGER, Id, pp. 960.

49 “The Lammy Review”, Id, pp.64.

${ }^{50}$ Mantouvalou, Virginia, quoting Justice RothSTEIN in "Labour Rights in the European Convention on Human Rights: An intellectual justification for an integrated approach to interpretation", European Human Rights Law Review, Vol. 13, No. 3, 2013, pp. 20.
} 
should be respected and implemented by the governments of all nations, as a bare minimum of what respect for human dignity requires, 51 .

In order to preserve human dignity, Nusbbaum believes that certain capabilities must be preserved by governments. The control of our own environment is in the ten capabilities list that she developed, and it includes the right to search for work without discrimination ${ }^{52}$. Considering this, Mantouvalou declares that the benefits of having work are tangibles and intangibles. On the one hand, having a job brings monetary stability, housing and goods. On the other hand, work leads intangible benefits which are related to a person's identity, selfconfidence and socialization. Those are benefits that are essential to freedom. Therefore, labor Rights must be considered as Human Rights. In that case, the government not only has to remove barriers and obstacles which interferes with liberties, but it must support people's capabilities. In this regard, when it comes to treat labor Rights as Human Rights, freedom is about choice - having more than one alternative- and real opportunities.

Accepting the Mantouvalou theory is not only about labelling the Right to work as a Human Right. After all, as she mentioned in her article, the ECtHR has already read the Right to work in the Art. 8 of the Convention ${ }^{53}$ and that leads, in our opinion, to the trap of "public safety" as the only objective of criminal records schemes. Her theory of "positive freedom", on the contrary, offers another perspective on this issue, because one can seriously concludes that criminal records are leaving ex-offenders without real opportunities to be free. As a result, the UK government pushes ex-offenders to unemployment, discrimination and delinquency. That kind of deprivation of liberty can be considered coercion since there is no real choice of act in any legal way. Inevitably, the UK, and other governments as well, must reevaluate the idea of stigmatizing people, some of them forever, because of their past. Even more, when affecting their access to work, the so-called public protection is at stake too.

\section{Final reflection}

The limits of the Convention, the Charter and the ILO legal framework to accomplish the reintegration of ex-offenders into society jeopardizes the rights of these persons to privacy and work. In that sense, examined the arguments of the ECtHR as to the legality of the UK criminal records schemes, it was quite clear that the Right to privacy is not deemed absolute,

\footnotetext{
${ }^{51} I d$, pp. 22.

52 Nusbaumm, Martha, “Crear capacidades: propuesta para el desarrollo humano, (trad. Albino Santos Mosquera) Barcelona, Ediciones Paidós, 2012.

${ }^{53} I d$, pp. 8 .
} 
and when it comes to ex-offenders, that Right should be balanced, taking into consideration the so-called public safety interest, governments are not willing to take any risks and, in doing so, they stigmatize an important group of its population. In the same way, it was imperative to show the Right to work limitations and the authorization in the ILO No. 111 Declaration and the Convention to discriminate when ex-offenders are searching for work.

Taking into consideration the above, the criminology findings about criminal records policies shed light into the mistaken belief of its main objective. The stigmatization of these persons does not make our societies more secure places. On the contrary, the schemes restrict the access to work of ex-offenders and pushes them into delinquency when leaving them without any real chances to legally survive. The civil remedies are not the solution either. As we saw, this type of remedies in the USA, tend to be constructed on another type of discrimination. But even worse, civil remedies are only a treatment after the fact. The solution must be eliminating any possible discrimination ex ante.

Mantouvalou's theory of "positive freedom" is presented in this work with the intention to approach this problem of social exclusion from a more ethical perspective. When governments pretend to reintegrate an ex-offender into society, some capabilities - in Nusbbaum terms - should be guaranteed. The search for work without discrimination is one of those. Ex -prisoners are being denied the access to work and therefore, their reintegration into society. Through these dynamics, ex-offenders cannot be considered as free persons, since they are acting without any real alternative. In that case, governments should remove to the minimum - or eliminate completely- all obstacles that ex-offenders face in their job search. The "ban the box" propositions, initiated in the USA and exported to the UK, must be seriously evaluated by governments.

\section{Bibliography}

AleXAnder, Michelle, The New Jim Crow: Mass Incarceration in the Age of Color Blindness, New York, The New Press, 2013.

ECHR (1997) Thlimmenos v. Greece, App. no. 34369/97.

ECHR (2008), Demir and Baycara v Turkey, (Application No. 34503/97):

ECHR (2012), M.M. v. United Kingdom, (Application no. 24029/07). 
EwING, Keith, “The Death of Social Europe”, King's Law Journal, Vol. 26, No. 1. 2015.

GARLAND, David, The culture of control”, University of Chicago Press, 2001.

In the matter of an application by Lorraine Gallagher for Judicial Review (Northern Ireland) $R$ (on the application of $P, G$ and $W$ ) (Respondents) $v$ Secretary of State for the Home Department and another (Appellants) $R$ (on the application of $P$ ) (Appellant) $v$ Secretary of State for the Home Department and others (Respondents), [2019] UKSC 3.

LAMMY, David, "The Lammy Review of Black, Asian, and Minority Ethnic (BAME) Representation in the Criminal Justice system: call for evidence”, 2017.

LARRAURI, Elena, "Populismo punitivo y como resistirlo", Jueces para la democracia, No. 55, Madrid, March, 2006.

LARRAURI, Elena and JACOBS, James, "Criminal record disclosure and the Right to privacy", Criminal Law Review, No. 10, 2014.

LARRAURI, Elena and JACOBS, James, "Disclosure of non-convictions records may violate the European Convention on Human Rights", Collateral Consequences Resource Center, January 30, 2015. (Recuperado de: https://ccresourcecenter.org/2015/01/30/criminal-recordprivacy-according-european-court-human-rights/)

Mantouvalou, Virginia, quoting Justice Rothstein in "Labour Rights in the European Convention on Human Rights: An intellectual justification for an integrated approach to interpretation", European Human Rights Law Review, Vol. 13, No. 3, 2013

Nusbaumm, Martha, "Crear capacidades: propuesta para el desarrollo humano, (trad. Albino Santos Mosquera) Barcelona, Ediciones Paidós, 2012.

NAYlor, Brown; PATTERSOn, Moyra and PitTARD, Marilyn, "In the shadow of a criminal record: proposing a just model of criminal record employment checks", Melbourne U. L.R. Vol. 32, No. 1, 2009

PAGER, Debra, "The mark of a criminal record", American Journal of Sociology, Vol. 108, No. 5, 2003. 
$R(L)$ v. Commissioner of Police of the Metropolis [2009] UKSC 3.

SHI HUI, "The Legislative Protection of the Equal Employment Right of Individuals with Criminal Records Based on the International Human Rights Law", Canadian Social Science 